\title{
Pemanfaatan Ampas Kedelai Menjadi Kerupuk Untuk Meningkatkan Keterampilan Masyarakat Desa Wakah Kecamatan Ngrambe Kabupaten Ngawi
}

\section{Utilization of Soybean Dregs Into Crackers To Improve the Skills of the Wakah Village Community of Ngrambe Subdistrict, Ngawi Regency}

\author{
${ }^{1}$ Raras Setyo Retno, ${ }^{2}$ Sri Utami, ${ }^{2}$ Wachidatul Linda Yuhanna \\ ${ }^{1}$ Jurusan Pendidikan Guru Sekolah Dasar, Fakultas Keguruan dan Ilmu pendidikan, \\ Universitas PGRI Madiun, Madiun \\ 2Jurusan Pendidikan Biologi, Fakultas Keguruan dan Ilmu pendidikan, Universitas PGRI \\ Madiun, Madiun
}

Korespondensi: R.S. Retno, rarassetyo86@gmail.com

Naskah Diterima: 13 September 2019. Disetujui: 22 Juni 2020. Disetujui Publikasi: 30 Juni 2020

\begin{abstract}
Wakah Village is one of the tofu industry villages in Ngrambe, Ngawi Regency. Tofu waste in Setono Village has not been used optimally. Solid tofu waste has nutritional content that can still be used as a potential culinary product. The product developed is soybean crackers. This community empowerment program was carried out in July 2019 with 30 participants. The method used is the delivery of material, making raw crackers, frying crackers, and packaging the product. In general, the training went well. The level of understanding of the material and skills of participants was $90 \%$. The result show that tofu industry waste can be used as soybean crackers. An increase in the knowledge and skills of the Wakah Village community in processing tofu industrial waste into soybean crackers.

Keywords: Pulp, soybean, crackers, Wakah.
\end{abstract}

\begin{abstract}
Abstrak. Desa Wakah merupakan salah satu desa industri tahu di Kecamatan Ngrambe Kabupaten Ngawi. Limbah tahu di Desa Setono belum dimanfaatkan secara optimal. Limbah tahu padat mempunyai kandungan gizi yang masih dapat digunakan sebagai produk kuliner yang potensial. Produk yang kembangkan adalah kerupuk ampas kedelai. Program pemberdayaan masyarakat ini dilakukan pada bulan Juli 2019 dengan peserta sejumlah 30 orang. Metode yang dilakukan adalah penyampaian materi, pembuatan kerupuk mentah, menggoreng kerupuk, dan mengemas produk. Secara umum pelatihan berjalan lancar. Tingkatpemahaman materi dan keterampilan peserta sejumlah $90 \%$. Hasil dari program ini adalah limbah industri tahu dapat dimanfaatkan menjadi kerupuk ampas kedelai. Adanya peningkatan pengetahuan dan keterampilan masyarakat Desa Wakah dalam mengolah limbah industri tahu menjadi kerupuk ampas kedelai.
\end{abstract}

Kata Kunci: Ampas, kedelai, kerupuk, Wakah.

\section{Pendahuluan}

Industri tahu merupakan salah satu unit usaha yang potensial, karena tahu merupakan makanan yang familiar di masyarakat. Pengolahan tahu menghasilkan limbah berupa ampas tahu berbentuk padat dan cair. Limbah padat berupa ampas kedelai, dan limbah cair berupa cairan yang menimbulkan bau yang menyengat 
dan menganggu lingkungan. Ampas tahu padat berupa ampas kedelai terdapat kandungan gizi yaitu protein $(23,55 \%)$, lemak $(5,54 \%)$, karbohidrat $(26,92 \%)$, abu $(17,03 \%)$, serat kasar $(16,5 \%)$, dan air(10,4\%) (Kaswinarni, 2008). Hal ini menunjukkan bahwa ampas tahu merupakan limbah yang dapat digunakan untuk produk yang lainnya. Limbah padat berupa ampas kedelai dapat dimodifikasi menjadi kerupuk ampas tahu (Rakhmawati \& Tripustikasari, 2018; Wirawan, Suliana \& Iskandar, 2017).

Pemberdayaan masyarakat merupakan salah bentuk kegiatan untuk meningkatkan keterampilan masyarakat berbasis kewirausahaan dalam menyelesaikan persoalan di daerahnya (Sujianto, 2019). Adanya sinergisitas antara akademisi, pemerintah dan masyarakat diharapkan dapat meningkatkan taraf hidup dan kesejahteraan. Desa Wakah Kecamatan Ngrambe merupakan salah satu penghasil tahu yang banyak menghasilkan limbah tahu dalam bentuk padat berupa ampas kedelai maupun bentuk cair. Permasalahan yang dihadapi mitra adalah limbah tahu sangat melimpah dan menganggu lingkungan, hanya dimanfaatkan sebagai pakan ternak dan belum terserap sepenuhnya, masyarakat belum memahami cara pengolahan limbah tahu. Sebagai upaya mengatasi permasalahan tersebut perlu inovasi untuk memanfaatkan limbah tahu menjadi produk yang bernilai guna.

Salah satu pemanfaatan limbah industri tahu berupa ampas kedelai adalah dengan dijadikan produk kuliner berupa ampas tahu. Kajian yang dilakukan oleh Yustina \& Abadi (2012) dan Isyanti \& Lestari (2014) mengenai potensi tepung dari ampas industri pengolahan kedelai sebagai bahan pangan, dimana tepung ampas kedelai mempunyai sifat fisiko kimia, fungsional dan mikrobiologi yang berpotensi sebagai bahan baku produk olahan kue kering, soy crackers, minuman, dan brownies (Rhohman \& Budiretnani, 2018). Diversifikasi produk olahan tahu diperlukan sebagai bentuk usaha sampingan yang mendatangkan income (Auliana et al, 2013; pangaribowo et al, 2017). Produk kuliner kerupuk ampas kedelai dibuat secara sederhana dan dapat dilakukan dalam skala rumah tangga. Produk Produk ini sangat potensial untuk dijadikan produk oleh-oleh wisata sekitar Desa Wakah. Potensi wisata di sekitar Desa Wakah antara lain Air Terjun Pengantin, Suwono Park, Kebun Teh Jamus dan Air Terjun Serambang. Adanya peluang yang baik dari aspek sumber daya alam dan sumber daya manusia ini dapat ditindaklanjuti menjadi program yang bermanfaat bagi masyarakat. Tujuan dari program ini adalah memanfaatkan limbah industri tahu menjadi produk kuliner berupa kerupuk ampas kedelai, meningkatkan pengetahuan dan keterampilan masyarakat Desa Wakah dalam mengolah limbah industri tahu menjadi kerupuk ampas kedelai.

\section{Metode Pelaksanaan}

Tempat dan Waktu. Program Pengabdian Masyarakat ini dilakukan di Desa Wakah Kecamatan Ngrambe Kabupaten Ngawi Jawa Timur. Waktu pelaksanaan adalah bulan Agustus 2019.

Khalayak Sasaran. Sasaran program ini terdiri dari seluruh anggota PKK Desa Wakah sejumlah 30 orang

Metode Pengabdian. Alat yang digunakan adalah baskom, blender, pisau, telenan, serk, pemotong kerupuk, plastik, dandang, tempat penjemuran, timbangan dan mesin pres. Bahan yang digunakan adalah ampas kedelai/ampas tahu, tepung tapioka, tepung terigu, bawang putih, udang ebi kering, garam, ketumbar, soda kue dan air. Metode yang di lakukan adalah 1) menyiapkan alat dan bahan, 2) memeras ampas kedelai dan mengukus sampai 15 menit, 3) menyiapkan bumbu berupa bawang putih, garam, ketumbar, ebi kering, 4) mencampur ampas kedelai, tepung tapioka, tepung terigu, bumbu dan soda kue, 5) menambah air hangat dan mencampur sampai bernentuk cairan, 6) memasukkan ke dalam plastik panjang, 
7) mengukus gulungan selama 30 menit, 8) mengangkat dan mendiamkan selama 1 malam, 9) memotong gulungan kerupuk, 10) menjemur kerupuk, 11) menggoreng kerupuk, 12) mengemas kerupuk.

Indikator Keberhasilan. Indikator keberhasilan meliputi 1) Adanya produk berupa kerupuk dari ampas kedelai. 2) Tingkat pemahaman peserta secara klasikal mencapai $75 \%$ dengan kriteria sangat baik dan baik.

Metode Evaluasi. Metode evaluasi yang digunakan adalah menggunakan angket pemahaman peserta yang terdiri dari 10 item pernyataan terkait proses pembuatan kerupuk ampas kedelai. Anget diberikan kepada peserta kemudian dianalisis sesuai dengan kriterianya. Kriteria penilaian pemahaman peserta adalah 0-10 (kurang baik), 11-20 (cukup baik), 21-30 (baik), 31-40 (sangat baik).

\section{A. Penyampaian Materi}

\section{Hasil dan Pembahasan}

Limbah ampas kedelai atau ampas tahu masih dapat digunakan menjadi produk kuliner. Salah satu produk kuliner sederhana dari pemanfataan limbah ampas kedelai adalah kerupuk. Pembuatan kerupuk ini cukup sederhana dan dapat dilakukan dalam skala rumahan. Pelatihan pembuatan kerupuk ampas kedelai ini berjalan sangat kondusif. Peserta sangat antusias dalam mengikuti kegiatan baik pemaparan secara teori maupun praktik. Kegiatan pelatihan ini diawali dengan pembukaan yang dihari oleh ketua PKK desa Wakah, Dinas Koperasi dan Usaha Mikro Kabupaten Ngawi dan tim PKM. Pembukaan ini disampaikan bahwa tujuan sdari kegiatan ini adalah pemberdayaan masyakat dalam mengolah limbah kedelai menjadi kerupuk. Tingkat kehadiran peserta mencapai 98\%. Penyampaian materi dilakukan oleh ketua tim PKM selama 1 jam. Materi mencakup konsep pemberdayaan masyarakat, potensi limbah tahu, alat, bahan, cara pembuatan dan pengemasan produk (Gambar 1).
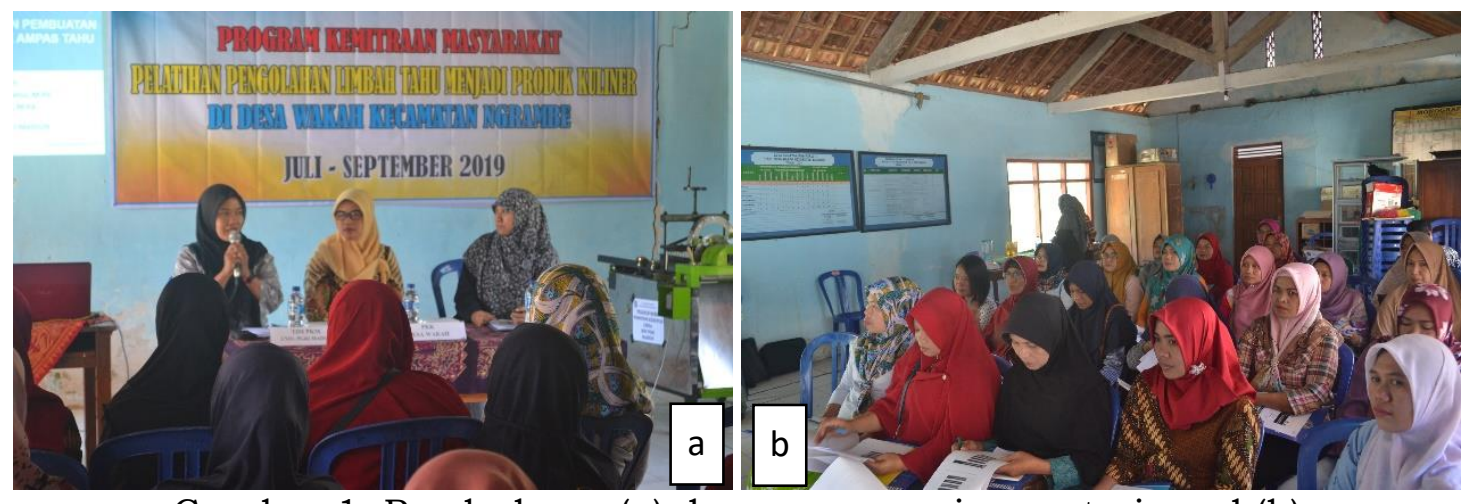

Gambar 1. Pembukaan (a) dan penyampaian materi awal (b)

\section{B. Pembuatan Kerupuk Mentah}

Acara pemaparan materi dilanjutkan dengan praktik pembuatan kerupuk ampas tahu. Alat yang digunakan adalah baskom, blender, pisau, telenan, serok, pemotong kerupuk, plastik, dandang, tempat penjemuran, timbangan dan mesin pres. Bahan yang digunakan adalah ampas kedelai/ampas tahu, tepung tapioka, tepung terigu, bawang putih, udang ebi kering, garam, ketumbar, soda kue dan air. Pembuatan kerupuk mentah dilakukan oleh ibu-ibu PKK mellaui praktek secara langsung. Adapun resep pembuatan kerupuk ampas tahu sebagimana tabel 1.

Hasil dari kegiatan ini adalah semua peserta dapat membuat kerupuk dari ampas kedelai. Peserta sangat antusias dan termotivasi untuk membuat dan mengembangkan usaha. Proses pertama yaitu memeras ampas kedelai sampai berkurang kadar airnya. Selanjutnya adalah mengukus ampas kedelai selama 15 
Tabel 1. Resep pembuatan kerupuk amaps kedelai

\begin{tabular}{ccc}
\hline No. & Nama Bahan & Ukuran \\
\hline 1. & Ampas tahu & $1 \mathrm{~kg}$ \\
2. & Tepung Kanji & $3 \mathrm{~kg}$ \\
3. & Tepung terigu & $0,5 \mathrm{~kg}$ \\
4. & Udang ebi & 1 ons \\
5. & Garam & 1 sendok teh \\
6. & Soda Kue & 1 sendok teh \\
7. & Ketumbar & 1 sendok teh \\
8. & Air hangat & Secukupnya \\
\hline
\end{tabular}

menit dengan tujuan untuk mematikan mikroba dari ampas kedelai. Pengukusan juga bertujuan untuk mematangkan ampas tahu sebelum diolah menjadi kerupuk. Selain dengan metode dikukus, ampas kedelai juga dapat dibuat tepung terlebih dahulu sebelum diproses menjadi produk kuliner (Rahayu, Sudrajat \& Rinihapsari, 2016). Langkah selanjutnya adalah menyiapkan bumbu dan tepung tambahan. Formulasi bumbu standar sebagaimana tebel 1, namun dapat dimodifikasisesuai selera. Ampas kedelai, bumbu, tepung terigu, soda kue dan tepung tapioka dicampur dengan menggunakan air hangat. Air hangat bertujuan untuk mempermudah pencampuran adonan agar tepung tidak menggumpal. Adonan dibuat dalam bentuk encer. Selanjutnya adonan encer dimasukkan ke dalam plastik untuk dikukus. Pengukusan dilakukan selama 30 menit sampai adonan keras dan matang. Setelah matang adonan dibiarkan semalam agar mengeras dan mudah untuk dipotong. Gulungan adonan yang telah mengeras dipotong menggunakan mesin pemotong kerupuk. Mesin ini mempunyai kapasitas $100 \mathrm{~kg}$ per jam dengan sumber tenaga listrik. Pemotongan dengan mesin pemotong kerupuk menghasilkan kerupuk dengan ketebalan yang sama dan bentuk yang seragam (Gambar 2).
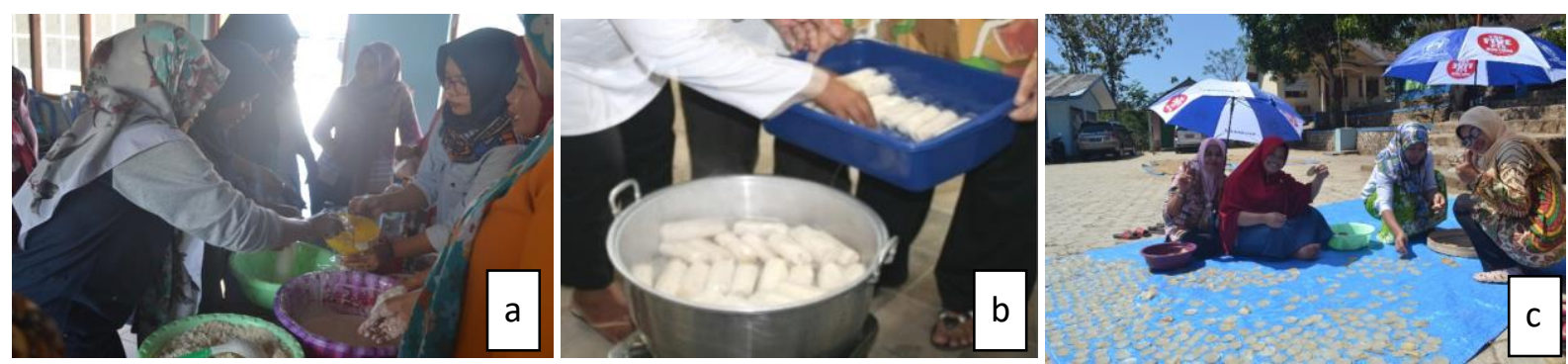

Gambar 2. Pembuatan adonan kerupuk ampas kedelai (a), Pengukusan kerupuk (b), Menjemur kerupuk (c)

Kerupuk yang sudah dipotong kemudian dijemur sampai benar-benar kering. Selain dengan menggunakan panas matahari, pengeringan juga dapat dilakukan dengan mesin pengering (Raliby \& Rusdjijati, 2010). Mesin pengering digunakan pada saat musim penghujan. Setelah kering kerupuk siap untuk digoreng. Pelaksanaan pembuatan kerupuk ampas kedelai ini berjalan lancar dan kondusif. Peserta secara aktif bertanya dan berdiskusi kepada tim untuk menghasilkan kerupuk yang baik. Masyarakat juga termotivasi untuk mengembangkannya menjadi home industry dan mendukung program Badan Uasaha Milik Desa (Bumdes). Selain itu juga masyarakat termotivasi untuk memasarkan kerupuk ampas kedelai di area wisata sekitar Desa wakah. 


\section{Penggorengan Kerupuk dan Pengemasan Kerupuk}

Peserta pelatihan setelah mendapatkan materi, membuat kerupuk mentah, maka dilanjutnya dengan penggorengan kerupuk. Kerupuk yang telah kering digoreng dengan panas sedang untuk menghasilkan kerupuk yang optimal. Setelah digoreng, kerupuk ditiriskan untuk mengurangi kadar minyak. Sebaiknya pengeringan minyak menggunakan mesin spinner, namun pada pelatihan ini belum dilakukan. Pengeringan dengan mesin spinner dilakukan untuk pendampingan selanjutnya. Proses setelah penggorengan yaitu pengemasan. Pengemasan dilakukan dengan menggunakan plastik flip kemasan pouch. Kemasan diberikan label agar produk dapat dikenali oleh masyarakat luas. Secara umum proses penggorengan dan pengemasan dilakukan dengan lancar, dan peserta memahami materi yang disampaikan (Gambar 3).
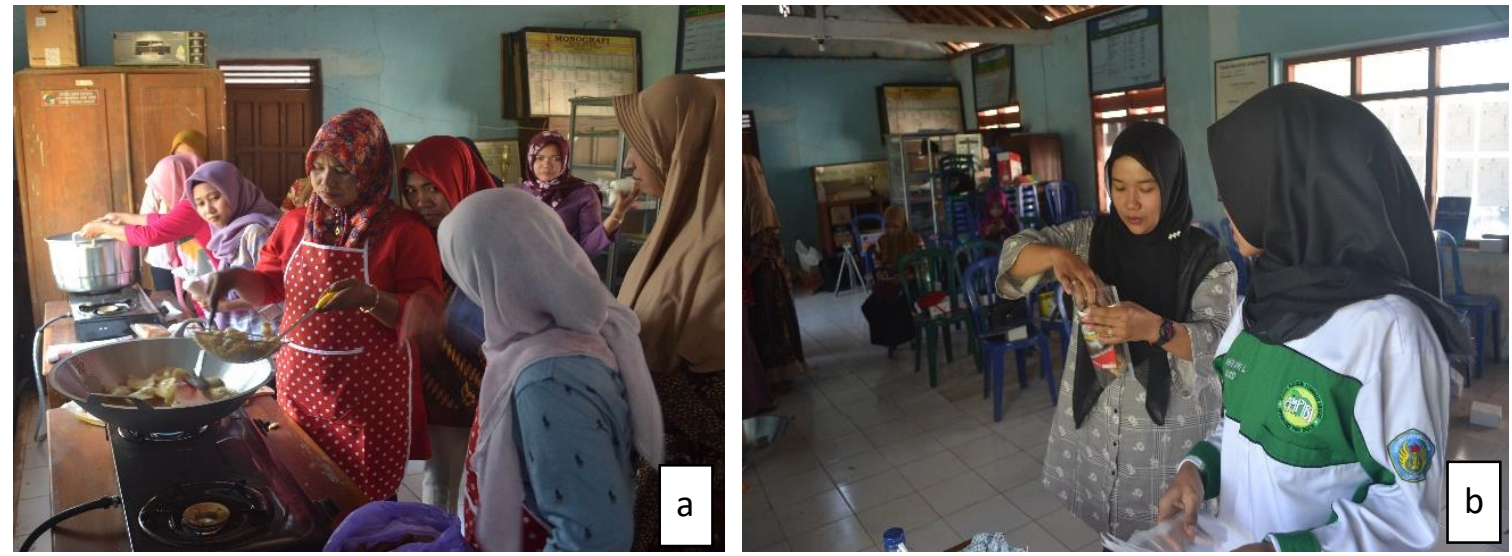

Gambar 3. Menggoreng kerupuk (a), mengemas kerupuk (b)

\section{Keberhasilan Kegiatan}

Berdasarkan angket yang dibagikan setelah kegiatan, maka dapat diketahui bahwa hasilnya adalah sebanyak $90 \%$ peserta memahami materi dan praktik yang disampaikan oleh tim. Sebagai upaya keberlanjutan maka tim PKM juga memberikan bantuan peralatan pendukung pembuatan kerupuk ampas kedelai. Tim juga membentuk kelompok desa binaan Universitas PGRI Madiun untuk proses pendampingan selanjutnya (Gambar 4).

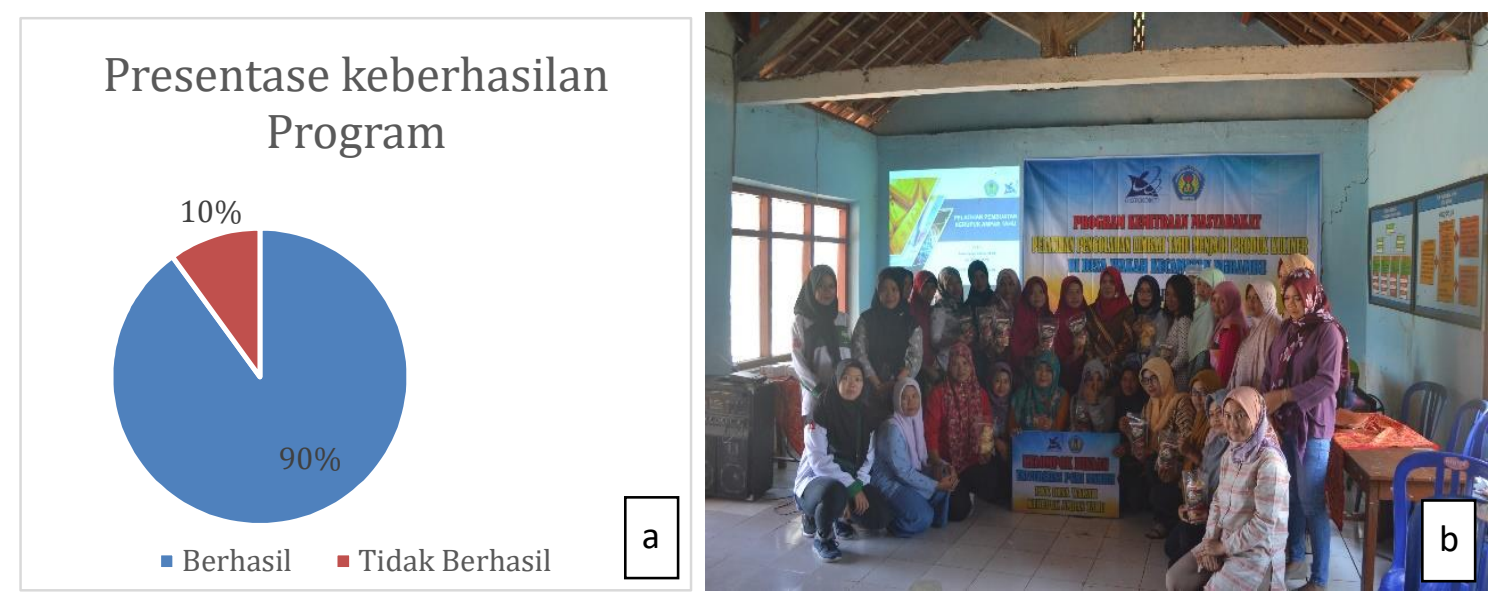

Gambar 4. Presentase keberhasilan program (a), Kelompok Binaan Universitas PGRI Madiun (b)

Dari diagram pada gambar 4 a menunjukkan prosentase kegiatan $90 \%$ berhasil, terbukti dengan antusiasme ibu-ibu PKK mengikuti kegiatan dari awal sampai 
akhir, meningkatnya pengetahuan dalam mengolah ampas tahu menjadi krupuk ampas tahu, banyaknya pertanyaan tentang manfaat dari limbah tahu serta respon positif terhadap ibu-ibu PKK yang tiap seminggu sekali melakukan produksi ampas tahu secara bergantian sekaligus memasarkan ke warung-warung dan pasar. Kegiatan ini sesuai dengan indikator yaitu lebih dari $75 \%$ peserta memahami materi yang disampaikan dengan kriteria baik dan sangat baik.

\section{Kesimpulan}

Telah dihasilkan produk kerupuk ampas tahu yang berasal dari limbah kedelai. Masyarakat Desa wakah sejumlah 90\% memahami dan terampil cara pembuatan kerupuk ampas kedelai dengan kriteria baik dan sangat baik.

\section{Ucapan Terima Kasih}

Tim PKM menyampaikan ucapan terimakasih kepada DRPM Kemenristekdikti yang telah memberikan bantuan pendanaan melalui Hibah Program Kemitraan Masyarakat tahun 2019, PKK DesaWakah, Dinas Koperasidan Usaha Mikro Kabupaten Ngawi, Pemerintah Desa Wakah, dan Universitas PGRI Madiun.

\section{Referensi}

Auliana, R., Hamidah, S., Rahmawati, F., \& Nugraheni, M. (2013). Pengembangan olahan tahu dan limbahnya berbasis teknologi pengawetan menuju diversifikasi produksi pasca erupsi. INOTEKS, 17(2).

Isyanti, M., \& Lestari, N. (2014). Perbaikan Mutu Gizi Produk Olahan Pangan Tradisonal Opak Ketan dengan Penambahan Tepung Ampas Tahu (Okara). Warta Industri Hasil Pertanian, 31(02), 62-69.

Kaswinarni, F. (2008). Kajian Teknis Pengolahan Limbah Padat dan Cair Industri Tahu. Majalah Lontar, 22(2).

Pangaribowo, D. A., Effendi, R., Kristiningrum, N., \& Purnamasary, I. (2017). Pemanfaatan Ampas Tahu sebagai Diversifikasi Produk Pangan dari Pengusaha Tahu di Kecamatan Kaliwates Jember.

Rahayu, L. H., Sudrajat, R. W., \& Rinihapsari, E. (2016). Teknologi Pembuatan Tepung Ampas Tahu Untuk Produksi Aneka Makanan Bagi Ibu-Ibu Rumah Tangga Di Kelurahan Gunungpati, Semarang. E-Dimas: Jurnal Pengabdian kepada Masyarakat, 7(1), 68-76.

Rakhmawati, D., \& Tripustikasari, E. (2018). Peningkatan Nilai Tambah Produksi Tahu Bagi Kelompok Produsen Tahu Di Sokaraja Tengah Kecamatan Sokaraja Kabupaten Banyumas. Adi Widya: Jurnal Pengabdian Masyarakat, 2(2), 1925.

Raliby, O., \& Rusdjijati, R. (2010). Perancangan Alat Pengering Kerupuk Dengan Memanfaatkan Gas Buang Dari Proses Produksi Pada Industri Pembuatan Kerupuk. Prosiding SNST Fakultas Teknik, 1(1).

Rhohman, F. \& Budiretnani, D.A. (2018). Optimalisasi Proses Produksi Tahu Untuk Peningkatan Kesejahteraan Produsen Tahu. Jurnal Panrita Abdi, 2(2), 113118.

Sujianto, A. E. (2019). Pendidikan Kewirausahaan Melalui Pelatihan Produksi Tahu Dan Kerupuk Okara Bagi Ibu Rumah Tangga Desa Bendiljati Kulon Kabupaten Tulungagung. J-ADIMAS (Jurnal Pengabdian kepada Masyarakat), 6(1).

Wirawan, W., Suliana, G., \& Iskandar, T. (2017). Pemanfaatan Ampas Tahu Untuk Olahan Pangan Dari Limbah Pengolahan Industri Tahu Di Kelurahan Tunggulwulung Kota Malang. JAPI (Jurnal Akses Pengabdian Indonesia), 2(1), 64-70. 
Yustina, I \& Abadi F. R. (2012). Potensi Tepung dari AmpasIndustri Pengolahan Kedelai sebagai Bahan Pangan. SeminarNasional Kedaulatan Pangan dan Energi.Fakultas PertanianUniversitas Trunojoyo Madura, Madura

Penulis:

Raras Setyo Retno, Jurusan Pendidikan Guru Sekolah Dasar, Fakultas Keguruan dan Ilmu Pendidikan Universitas PGRI Madiun, Madiun. E-mail: rarassetyo86@gmail.com

Sri Utami, Jurusan Pendidikan Biologi, Fakultas Keguruan dan Ilmu Pendidikan Universitas PGRI Madiun, Madiun. E-mail: sriutami@unipma.ac.id

Wachidatul Linda Yuhanna, Jurusan Pendidikan Biologi, Fakultas Keguruan dan Ilmu Pendidikan Universitas PGRI Madiun, Madiun. E-mail: linda.yuhanna.wiguno@gmail.com

Bagaimana men-sitasi artikel ini:

Retno, R.S., Utami, S., \& Yuhanna, W.L. (2020). Pemanfaatan Ampas Kedelai Menjadi Kerupuk Untuk Meningkatkan Keterampilan Masyarakat Desa Wakah. Jurnal Panrita Abdi, 4(3), 298304. 